\title{
The benefits of youth are lost on the young cardiac arrest
}

\section{patient [version 1; peer review: 2 approved]}

\author{
Brian Griffith1, Patrick Kochanek1-3, Cameron Dezfulian 1,2,4,5 \\ ${ }^{1}$ Safar Center for Resuscitation Research, University of Pittsburgh School of Medicine, Pittsburgh, Pennsylvania, USA \\ ${ }^{2}$ Department of Critical Care Medicine, University of Pittsburgh School of Medicine, Pittsburgh, Pennsylvania, USA \\ ${ }^{3}$ Pediatrics, University of Pittsburgh School of Medicine, Pittsburgh, Pennsylvania, USA \\ ${ }^{4}$ Clinical and Translational Sciences, University of Pittsburgh School of Medicine, Pittsburgh, Pennsylvania, USA \\ ${ }^{5}$ Vascular Medicine Institute, University of Pittsburgh School of Medicine, Pittsburgh, Pennsylvania, USA
}

V1 First published: 25 Jan 2017, 6(F1000 Faculty Rev):77

https://doi.org/10.12688/f1000research.9316.1

Latest published: 25 Jan 2017, 6(F1000 Faculty Rev):77

https://doi.org/10.12688/f1000research.9316.1

\section{Abstract}

Children and young adults tend to have reduced mortality and disability after acquired brain injuries such as trauma or stroke and across other disease processes seen in critical care medicine. However, after out-of-hospital cardiac arrest (OHCA), outcomes are remarkably similar across age groups. The consistent lack of witnessed arrests and a high incidence of asphyxial or respiratory etiology arrests among pediatric and young adult patients with OHCA account for a substantial portion of the difference in outcomes. Additionally, in younger children, differences in pre-hospital response and the activation of developmental apoptosis may explain more severe outcomes after OHCA. These require us to consider whether present practices are in line with the science. The present recommendations for compression-only cardiopulmonary resuscitation in young adults, normothermia as opposed to hypothermia $\left(33^{\circ} \mathrm{C}\right)$ after asphyxial arrests, and paramedic training are considered within this review in light of existing evidence. Modifications in present standards of care may help restore the benefits of youth after brain injury to the young survivor of OHCA.

Keywords

Cardiac arrest, Paediatric, Resuscitation

\section{Open Peer Review \\ Approval Status \\ 1 \\ 2 \\ version 1 \\ 25 Jan 2017 \\ Faculty Reviews are review articles written by the prestigious Members of Faculty Opinions. The articles are commissioned and peer reviewed before publication to ensure that the final, published version is comprehensive and accessible. The reviewers who approved the final version are listed with their names and affiliations. \\ 1. Tobias Cronberg, Lund University, Lund, Sweden \\ 2. Hideo Inaba, Kanazawa University Graduate School of Medicine, Kanazawa, Japan} Any comments on the article can be found at the end of the article. 
Corresponding author: Cameron Dezfulian (dezfulianc@upmc.edu)

Competing interests: The authors declare that they have no competing interests.

Grant information: The author(s) declared that no grants were involved in supporting this work.

Copyright: $\odot 2017$ Griffith B et al. This is an open access article distributed under the terms of the Creative Commons Attribution License , which permits unrestricted use, distribution, and reproduction in any medium, provided the original work is properly cited. Data associated with the article are available under the terms of the Creative Commons Zero "No rights reserved" data waiver (CC0 1.0 Public domain dedication).

How to cite this article: Griffith B, Kochanek P and Dezfulian C. The benefits of youth are lost on the young cardiac arrest patient [version 1; peer review: 2 approved] F1000Research 2017, 6(F1000 Faculty Rev):77 https://doi.org/10.12688/f1000research.9316.1

First published: 25 Jan 2017, 6(F1000 Faculty Rev):77 https://doi.org/10.12688/f1000research.9316.1 


\section{Introduction}

Outcomes by age in acute neurologic injuries tend to favor youth. When stratified by age, younger age groups tend to have improved rates of mortality and favorable neurologic recovery in traumatic brain injury $(\mathrm{TBI})^{1-3}$ and stroke ${ }^{4-6}$, including both intracerebral ${ }^{7,8}$ and subarachnoid ${ }^{9}$ hemorrhages. Children and young adults have fewer comorbidities and more reserve by virtue of their youth. It is well known that vascular disease increases with each decade of life ${ }^{10}$ such that one would expect far better cerebral and coronary blood flow assuming that the same quality of cardiopulmonary resuscitation (CPR) was administered. Age-predicted functional and electroencephalogram recovery from intracarotid amobarbital ${ }^{11}$ is consistent with the fact that younger brains are either more resistant to the insult or faster to recover. After TBI, younger patients compared with older ones with a similar disability score at admission to rehabilitation exhibited increased recovery after 1 and 5 years ${ }^{1}$.

Indeed, this pattern of less mortality and disability with younger age is observed throughout critical care and medicine. Yet after out-of-hospital cardiac arrest (OHCA), outcomes are remarkably similar in both the short and long term when comparing pediatric and adult patients (Table 1). This remains the case in nations where pre-hospital termination of resuscitation efforts is not permitted (Table 2). Survival to hospital discharge and good neurologic function at discharge and 1 month are all below $10 \%$ in most studies. It is only when one considers long-term outcomes that children appear to have a slight advantage in outcome.

\section{Explanations for the lack of neurologic protection in younger out-of-hospital cardiac arrest}

The consistent lack of witnessed arrests among pediatric OHCA, particularly in infants and preschool children, accounts for a substantial portion of the mortality (Table 3). In the case of infants, most deaths occur during sleep and are attributed to sudden infant death syndrome (most of the "Other etiology" in infants on Table 3) or suffocation ${ }^{12-15}$. In preschool- and early school-aged children, asphyxia from drowning, choking, or suffocation ${ }^{15}$ again occurs often out of immediate sight of an adult. Indeed, having OHCA at home is an independent predictor of worse outcome in some OHCA studies ${ }^{15}$. In older children (for example, adolescents) and young adults, OHCA is often unwitnessed as it is the result of suicide or substance abuse with overdose $\mathrm{e}^{12,13,15-17}$. A recent report from the Resuscitation Outcomes Consortium (ROC) documents the fact that increasing overdose deaths tend to occur in young adults and tend to be unwitnessed ${ }^{16}$.

Since it is uncertain when the precise time of CA occurs, the noflow times can be substantial. In our personal experience (since this is rarely reported), many of these children are noted to be cyanotic and lifeless by their parents when CPR is first begun, and epidemiologic reports confirm asystole as the most frequent presenting rhythm ${ }^{12,13}$. Young hearts fare much better than young brains as evidenced by return of spontaneous circulation (ROSC) rates of $30 \%$ or better ${ }^{12,13}$ (despite the lack of a witness in most cases), which are comparable to that of witnessed adult non-shockable $\mathrm{OHCA}^{18}$. Infants were the only group in the large Japanese data set who had a lower incidence of $\mathrm{ROSC}^{19}$. This may reflect a somewhat enhanced capacity of the heart to tolerate ischemia ${ }^{20}$ compared with the brain.
The fact that many arrests are indeed unwitnessed resulted in the observation that bystander CPR rates, though not dissimilar to those of other age groups, did not improve outcomes ${ }^{12,13}$. Presumably, CPR started by bystanders on younger patients is occurring later after the onset of no flow since a larger proportion of pediatric OHCA is unwitnessed (that is, the patient is found in no flow of uncertain duration). Bystander CPR initiated later in no flow likely lacks the benefits imparted by prompt bystander CPR in a randomized study of older adults ${ }^{21}$.

The second important factor explaining why pediatric and young adult OHCA patients do not fare better is the extremely high incidence of asphyxial or respiratory etiology arrests as opposed to cardiac etiology. This is particularly true after infancy (when many congenital defects account for cardiac death) through young adulthood (Table 3). Outcome also appears to vary on the basis of etiology, although this association is controversial. We previously found worsened neurologic outcomes and survival associated with non-cardiac etiology $\mathrm{OHCA}^{22}$, which was likewise noted in the Korean Hypothermia Network (KORHN) registry ${ }^{23}$, whereas the opposite association was noted by the $\mathrm{ROC}^{24}$. Cardiac etiology OHCA tends to present with ventricular fibrillation and ventricular tachycardia, whereas non-cardiac etiology CA, such as asphyxia, often presents with pulseless electrical activity or asystole as a first rhythm ${ }^{25,26}$. Shockable rhythms are well known to yield the best outcomes ${ }^{23,24,27,28}$, even in children ${ }^{29}$. In the recently reported pediatric hypothermia study (THAPCA-OHCA) ${ }^{30}$, asphyxial OHCA accounted for more than $70 \%$ of all OHCA, and shockable rhythms were present in fewer than $10 \%$ of cases. This is compared with incidences of approximately $24 \%$ shockable rhythm in adult $\mathrm{OHCA}^{27,28}$. Young adults, who tend to make up the majority of overdose-related OHCA, generally present with non-shockable rhythms ${ }^{16}$. Although it remains uncertain why asphyxial CA confers more severe outcomes, this observation has been consistently made in experimental comparisons of different forms of CA where insult time is matched ${ }^{31,32}$. Yet treatment of OHCA patients after ROSC is the same regardless of rhythm or etiology ${ }^{33}$; the only difference is that coronary angiography is recommended in suspected cardiac etiology CA due to acute coronary occlusion ${ }^{16}$.

The low incidence of pediatric OHCA relative to adult OHCA also means that paramedics are unlikely to have much repetition with resuscitation annually. With most things in medicine, "practice makes perfect"; therefore, low incidence means little practice. This is confounded by the added complexity resulting from pediatric life support $^{34,35}$, which demands variable dosing and equipment sizing based on age and uses different algorithms than adult basic and advanced life support ${ }^{36,37}$. It is no surprise that in anonymous surveys paramedics report far less comfort with their technical skills in pediatric resuscitation and far less experience ${ }^{38}$. Compliance with American Heart Association (AHA) guidelines for rate and depth is significantly improved in "adult size" adolescents compared with children who are 1 to 11 years old ${ }^{39}$ achieving compliance rates comparable to that seen in adults within the same registry ${ }^{40,41}$.

In the past decade, the concept of developmental apoptosis has been identified and characterized ${ }^{42}$. It appears that the cellular and molecular machinery used for normal pruning of neurons prior to 


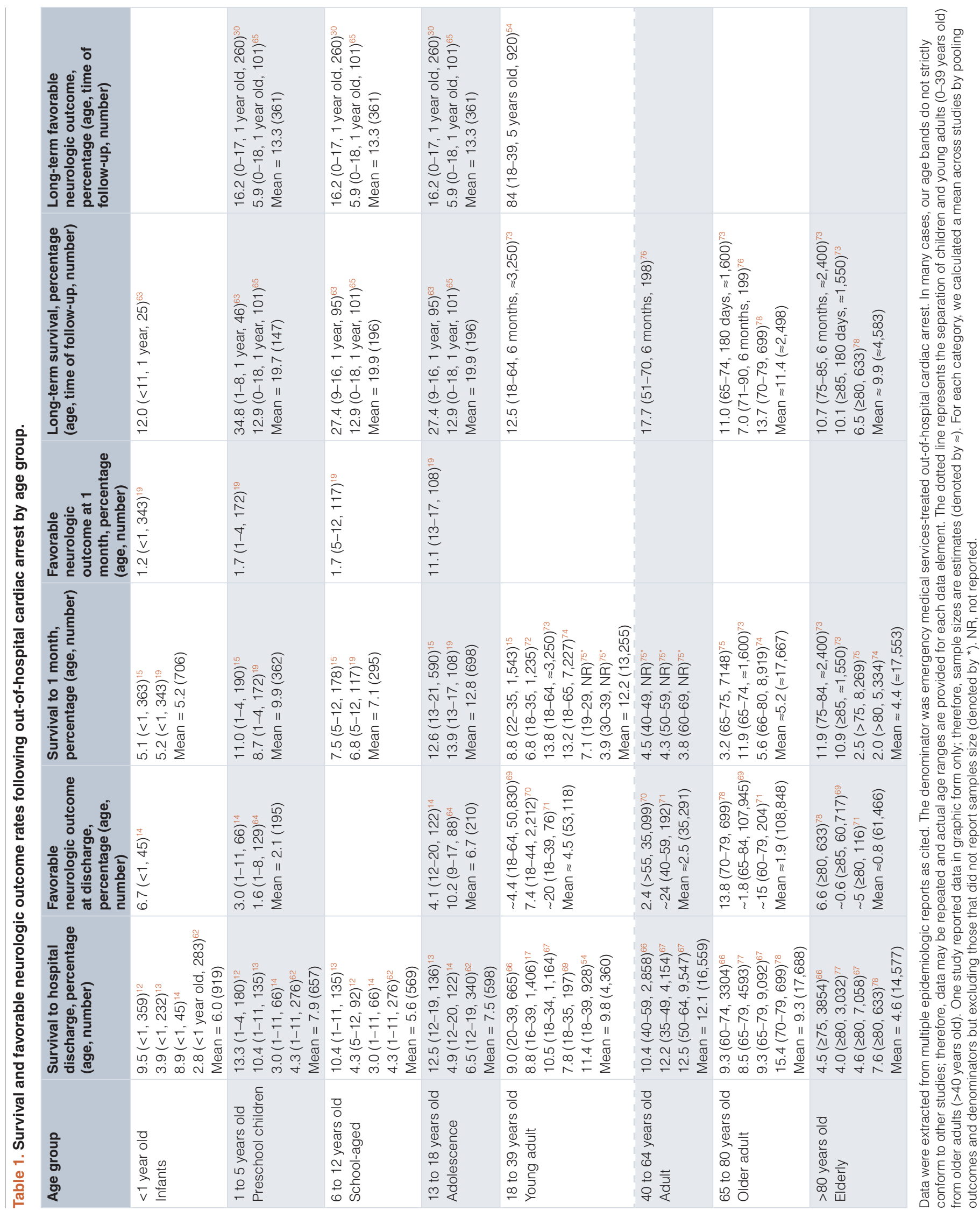







Table 3. Etiology and witnessed status of out-of-hospital cardiac arrest by age group.

\begin{tabular}{|c|c|c|c|c|}
\hline $\begin{array}{l}\text { Approximate age } \\
\text { division }\end{array}$ & $\begin{array}{l}\text { Cardiac etiology, } \\
\text { percentage (age, } \\
\text { number) }\end{array}$ & $\begin{array}{l}\text { Respiratory } \\
\text { etiology, percentage } \\
\text { (age, number) }\end{array}$ & $\begin{array}{l}\text { Other etiology, } \\
\text { percentage (age, } \\
\text { number) }\end{array}$ & $\begin{array}{l}\text { Witnessed arrest, } \\
\text { percentage (age, } \\
\text { number) }\end{array}$ \\
\hline $\begin{array}{l}<1 \text { year old } \\
\text { Newborn }\end{array}$ & $\begin{array}{l}12(<1,363)^{15} \\
11(<1,276)^{72} \\
39(<1,29)^{14} \\
34(<1,347)^{19} \\
\text { Mean = } 20(1,015)\end{array}$ & $\begin{array}{l}6(<1,363)^{15} \\
7(<1,276)^{72} \\
37(<1,347)^{19} \\
\text { Mean }=17(986)\end{array}$ & $\begin{array}{l}82(<1,363)^{5} \\
82(<1,276)^{72} \\
29(<1,347)=19 \\
\text { Mean = 63 }(986)\end{array}$ & $\begin{array}{l}28(<1,363)^{5} \\
26(<1,276)^{2} \\
17(<1,277)^{3} \\
10(<1,343)^{19} \\
\text { Mean = } 20(1,259)\end{array}$ \\
\hline $\begin{array}{l}1 \text { to } 5 \text { years old } \\
\text { Preschool children }\end{array}$ & $\begin{array}{l}11(1-4,190)^{15} \\
13(1-4,136)^{72} \\
28(1-11,18)^{14} \\
31(1-4,203)^{19} \\
\text { Mean }=20(547)\end{array}$ & $\begin{array}{l}39(1-4,190)^{15} \\
38(1-4,136)^{72} \\
38(1-4,203)^{19} \\
\text { Mean }=38(529)\end{array}$ & $\begin{array}{l}50(1-4,190)^{15} \\
45(1-4,136)^{72} \\
31(1-4,203)^{19} \\
\text { Mean }=41(529)\end{array}$ & $\begin{array}{l}34(1-4,190)^{15} \\
34(1-4,136)^{72} \\
32(1-11,154)^{13} \\
39(1-8,129)^{64} \\
31(1-4,172)^{19} \\
\text { Mean = 34 (781) }\end{array}$ \\
\hline $\begin{array}{l}6 \text { to } 12 \text { years old } \\
\text { School-aged }\end{array}$ & $\begin{array}{l}13(5-12,178)^{15} \\
14(5-12,142)^{72} \\
30(5-12,135)^{19} \\
\text { Mean }=18(455)\end{array}$ & $\begin{array}{l}30(5-12,178)^{15} \\
30(5-12,142)^{72} \\
37(5-12,135)^{19} \\
\text { Mean }=32(455)\end{array}$ & $\begin{array}{l}57(5-12,178)^{15} \\
56(5-12,142)^{72} \\
33(5-12,135)^{19} \\
\text { Mean }=50(455)\end{array}$ & $\begin{array}{l}51(5-12,178)^{15} \\
56(5-12,142)^{72} \\
34(5-12,117)^{19} \\
\text { Mean }=48(437)\end{array}$ \\
\hline $\begin{array}{l}13 \text { to } 17 \text { years old } \\
\text { Adolescent }\end{array}$ & $\begin{array}{l}14(13-21,590)^{15} \\
20(13-17,148)^{72} \\
33(12-20,22)^{14} \\
25(13-17,190)^{19} \\
\text { Mean = } 18(950)\end{array}$ & $\begin{array}{l}26(13-21,590)^{15} \\
31(13-17,148)^{72} \\
24(13-17,190)^{19} \\
\text { Mean }=26(928)\end{array}$ & $\begin{array}{l}60(13-21,590)^{15} \\
49(13-17,148)^{72} \\
57(13-17,190)^{19} \\
\text { Mean }=58(928)\end{array}$ & $\begin{array}{l}42(13-21,590)^{15} \\
51(13-17,148)^{72} \\
25(12-19,193)^{13} \\
49(9-17,88)^{64} \\
46(13-17,108)^{19} \\
\text { Mean }=41(1,127)\end{array}$ \\
\hline $\begin{array}{l}18 \text { to } 39 \text { years old } \\
\text { Young adult }\end{array}$ & $\begin{array}{l}15(22-35,1,543)^{15} \\
15(18-35,1,235)^{72} \\
20(16-39,3,912)^{17} \\
21(18-35,197)^{68} \\
57(18-39,106)^{54} \\
60(18-64,7,810)^{75} \\
\text { Mean }=40(14,803)\end{array}$ & $\begin{array}{l}35(22-35,1,543)^{15} \\
33(18-35,1,235)^{72} \\
33(18-39,106)^{54} \\
12(18-64,7,810)^{75} \\
\text { Mean }=18(10,694)\end{array}$ & $\begin{array}{l}50(22-35,1,543)^{15} \\
52(18-35,1,235)^{72} \\
10(18-39,106)^{54} \\
28(18-64,7,810)^{75} \\
\text { Mean = 34 }(10,694)\end{array}$ & $\begin{array}{l}43(22-35,1,543)^{15} \\
50(18-35,1,235)^{72} \\
24(16-39,3,912)^{17} \\
46(18-35,197)^{68} \\
70(18-39,106)^{54} \\
\text { Mean }=34(6,993)\end{array}$ \\
\hline $\begin{array}{l}40 \text { to } 64 \text { years old } \\
\text { Adult }\end{array}$ & $\begin{array}{l}61(36-64,10,742)^{72} \\
83(\geq 40,26,094)^{17} \\
\text { Mean }=77(36,836)\end{array}$ & $13(36-64,10,742)^{72}$ & $26(36-64,10,742)^{72}$ & $\begin{array}{l}67(36-64,10,742)^{72} \\
33(\geq 40,26,094)^{17} \\
\text { Mean }=43(36,836)\end{array}$ \\
\hline $\begin{array}{l}65 \text { to } 80 \text { years old } \\
\text { Older adult }\end{array}$ & $\begin{array}{l}79(65-79,17,071)^{72} \\
81(65-75,7,261)^{75} \\
86(65-79,9,609)^{75} \\
\text { Mean }=81(33,941)\end{array}$ & $\begin{array}{l}9(65-79,17,071)^{73} \\
7(65-75,7,261)^{75} \\
\text { Mean }=8(24,332)\end{array}$ & $\begin{array}{l}12(65-79,17,071)^{72} \\
12(65-75,7,261)^{75} \\
\text { Mean }=12(24,332)\end{array}$ & $\begin{array}{l}71(65-79,17,071)^{72} \\
67(65-75,7,261)^{75} \\
35(65-79,9,609)^{77} \\
51(66-80,8,919)^{74} \\
\text { Mean }=58(42,860)\end{array}$ \\
\hline $\begin{array}{l}>80 \text { years old } \\
\text { Elderly }\end{array}$ & $\begin{array}{l}79(\geq 80,9,095)^{72} \\
83(>75,8,390)^{75} \\
90(80-89,6,430)^{77} \\
\text { Mean }=83(23,915)\end{array}$ & $\begin{array}{l}7(\geq 80,9,095)^{72} \\
6(>75,8,390)^{75} \\
\text { Mean }=7(17,485)\end{array}$ & $\begin{array}{l}14(\geq 80,9,095)^{72} \\
11(>75,8,390)^{75} \\
\text { Mean }=13(17,485)\end{array}$ & $\begin{array}{l}73(\geq 80,9,095)^{72} \\
65(>75,8,390)^{75} \\
31(80-89,6,430)^{77} \\
52(>80,5,334)^{74} \\
\text { Mean }=58(29,249)\end{array}$ \\
\hline
\end{tabular}

Data were extracted from multiple epidemiologic reports as cited. In many cases, our age bands do not strictly conform to other studies; therefore, data may be repeated and actual age ranges are provided for each data element. The dotted line represents the separation of children and young adults (0-39 years old) from older adults ( $>40$ years old). 
birth and in infancy can be activated by sustained exposure to some sedatives or anesthetics (or both) with use consistent with what might be encountered with operating room or pediatric intensive care unit management or both ${ }^{43}$. Impairment of neurogenesis may also be operating ${ }^{44}$. The result of these developmental phenomena is that in children apoptosis may be accelerated, exceeding what is normally seen as a result of global ischemia-reperfusion injury and thus precipitating a more severe injury. This mechanism could contribute to poorer-than-anticipated outcomes after cardiac arrest in infants, although the upper age limit for potential contribution of this mechanism remains to be determined ${ }^{45,46}$. However, the quantitative contribution of this molecular disadvantage in infants to outcome after ischemic insults to the brain remains to be defined.

\section{Implications for management}

The significant differences between the older adult and pediatric/ young adult populations are important issues to consider for management. Since 2008, the AHA has recommended chest compression-only CPR (COCPR) for adults who have an OHCA that is witnessed by a bystander ${ }^{47}$. This was based on pre-clinical and human observational data in adults that showed equivalent or improved outcomes when COCPR was used ${ }^{48-53}$. Pragmatically, COCPR is easier to teach and instruct (for 911 dispatchers) and results in fewer interruptions of CPR for rescue breaths as well as perhaps lower intrathoracic pressure (increasing coronary perfusion pressure). However, it must be noted that COCPR is ineffective in the pediatric population ${ }^{29}$. In this study, COCPR had similar outcomes to standard CPR only among pediatric patients with arrests of cardiac origin, a distinct minority (Table 3 ).

The AHA's call to action is intended "for bystanders [and] does not apply to unwitnessed cardiac arrest, cardiac arrest in children, or cardiac arrest presumed to be of non-cardiac origin", nor does it apply to paramedics who can provide full $\mathrm{CPR}^{47}$. In practice, however, this distinction is not conveyed to the public or appreciated by 911 operators; we routinely care for asphyxial OHCA patients who have received COCPR. For children who had OHCA from non-cardiac causes, full CPR with rescue breathing yielded higher odds of ROSC, 1-month survival, and neurologically intact survival $^{29}$. When Ogawa and colleagues examined this issue in the same national database (Japan), they found a similar trend to better outcomes with full CPR (versus COCPR) in the 20- to 39-yearold cohort, which was fully explained by better outcomes in the non-cardiac etiology subset ${ }^{51}$. Given the high prevalence of drug overdoses for arrest etiology in adolescents and young adults ${ }^{15,54}$, the now-dominant practice of instructing COCPR needs to be questioned if not modified to teach standard CPR in the younger population. Given that it is often easiest to teach a single approach and that outcomes from arrests of cardiac origin were not different in standard CPR versus COCPR, it would seem preferable to teach standard CPR for use across the full pediatric/young adult setting.

Differences in the characteristics of OHCA among patient populations are important when considering therapeutic hypothermia following OHCA. Two trials involving adult patients showed that therapeutic hypothermia improved neurologic outcomes in comatose survivors of OHCA with shockable rhythms compared with no temperature control ${ }^{55}$ or relaxed normothermia ${ }^{56}$. Interestingly, when comparing temperature management targeting $33^{\circ} \mathrm{C}$ versus $36^{\circ} \mathrm{C}$ after $\mathrm{OHCA}$, the Targeted Temperature Management (TTM) trial found no significant difference in outcomes between groups ${ }^{57}$. It should be noted that all of these studies recruited only patients with OHCA of presumed cardiac etiology ${ }^{55-57}$. In the underpowered ( $\mathrm{n}=260$ compared with $\mathrm{n}=939$ in TTM) pediatric THAPCAOHCA study, Moler and colleagues found a trend $(P=0.14)$ toward benefit for hypothermia $\left(33^{\circ} \mathrm{C}\right)$ compared with the normothermia $\operatorname{arm}\left(36.8^{\circ} \mathrm{C}\right)^{30}$ with a number needed to treat of 12 and no increase in adverse outcomes. Compared with the adult studies, the pediatric THAPCA-OHCA study recruited primarily respiratory etiology $(72 \%)$ non-shockable (>90\%) OHCA. Present AHA guidelines ${ }^{33}$ do not distinguish the temperature target for cardiac versus respiratory etiology $\mathrm{OHCA}^{33}$, leaving open the option to select any value from $32^{\circ} \mathrm{C}$ to $36^{\circ} \mathrm{C}$ in adults. In pediatrics, the present guidelines ${ }^{34}$ leave open the option to cool $\left(32-34^{\circ} \mathrm{C}\right)$ or stay warm $\left(36-37.5^{\circ} \mathrm{C}\right)$. Substantial pre-clinical evidence supports the benefits of deeper hypothermia $\left(33^{\circ} \mathrm{C}\right)$ even when delayed for several hours in asphyxial $\mathrm{CA}^{58}$. Given the existing data, one must question whether pediatric and young adult OHCA survivors, particularly those known to have had non-cardiac etiology OHCA, would not benefit from a lower temperature goal. When temperature strategies are compared ${ }^{30,57}$, it would appear that the potential benefits of cooling asphyxial arrest survivors outweigh the risks. Hypothermia has been suggested in pre-clinical studies to have specific protective effects against developmental apoptosis and this may also contribute to its efficacy in newborn asphyxia ${ }^{60}$.

With regard to paramedic performance in the setting of pediatric arrests, recent studies have demonstrated the challenge for paramedic providers in the setting of OHCA in children given how rarely they are encountered in routine paramedic practice ${ }^{60}$. However, simulation approaches applied systematically across multiple paramedic systems are being evaluated, as is the analysis of the specific errors that are most frequently observed in this setting ${ }^{61}$.

\section{Conclusions}

Given the unique facets of CA in children and young adults and the emerging importance of the opioid epidemic, we believe that a careful re-examination of our current care in regard to resuscitation training and temperature management is vital and that new investigation is crucial to optimizing outcomes in what should be a resilient population.

\section{Competing interests}

The authors declare that they have no competing interests.

\section{Grant information}

The author(s) declared that no grants were involved in supporting this work. 
1. Marquez de la Plata CD, Hart T, Hammond FM, et al.: Impact of age on longterm recovery from traumatic brain injury. Arch Phys Med Rehabil. 2008; 89(5): 896-903.

PubMed Abstract | Publisher Full Text | Free Full Text

2. Dhandapani S, Manju D, Sharma B, et al.: Prognostic significance of age in traumatic brain injury. J Neurosci Rural Pract. 2012; 3(2): 131-5. PubMed Abstract | Publisher Full Text | Free Full Text

3. Gómez PA, Lobato RD, Boto GR, et al:: Age and outcome after severe head injury. Acta Neurochir (Wien). 2000; 142(4): 373-80; discussion 380-1. PubMed Abstract | Publisher Full Text

4. Giroud M, Lemesle M, Madinier G, et al:: Stroke in children under $\mathbf{1 6}$ years of age. Clinical and etiological difference with adults. Acta Neurol Scand. 1997; 96(6): 401-6.

Pub(6): 401-6.

5. Kong KH, Chan KF, Tan ES: Functional outcome in young strokes. Ann Acad Med Singapore. 1995; 24(1): 172-6.

PubMed Abstract

6. Ween JE, Alexander MP, D'Esposito M, et al.: Factors predictive of stroke outcome in a rehabilitation setting. Neurology. 1996; 47(2): 388-92.

PubMed Abstract | Publisher Full Text

7. Fogelholm R, Murros K, Rissanen A, et al.: Long term survival after primary intracerebral haemorrhage: a retrospective population based study. J Neurol Neurosurg Psychiatry. 2005; 76(11): 1534-8.

PubMed Abstract | Publisher Full Text | Free Full Text

8. Morgan T, Zuccarello M, Narayan R, et al:: Preliminary findings of the minimally invasive surgery plus rtPA for intracerebral hemorrhage evacuation (MISTIE) clinical trial. Acta Neurochir Suppl. 2008; 105: 147-51.

PubMed Abstract | Publisher Full Text

9. Lanzino G, Kassell NF, Germanson TP, et al:: Age and outcome after aneurysmal subarachnoid hemorrhage: why do older patients fare worse? J Neurosurg. 1996; 85(3): 410-8

PubMed Abstract | Publisher Full Text

10. F Savji N, Rockman CB, Skolnick $\mathrm{AH}$, et al:: Association between advanced age and vascular disease in different arterial territories: a population databas of over 3.6 million subjects. J Am Coll Cardiol. 2013; 61(16): 1736-43. PubMed Abstract | Publisher Full Text | F1000 Recommendation

11. Segal JB, Moo LR, Hart J Jr: : The effect of age on rate of functional recovery after intracarotid amobarbital injection. Epilepsia. 2002; 43(6): 659-61. PubMed Abstract | Publisher Full Text

12. Young KD, Gausche-Hill M, McClung CD, et al:: A prospective, populationbased study of the epidemiology and outcome of out-of-hospital pediatric cardiopulmonary arrest. Pediatrics. 2004; 114(1): 157-64. PubMed Abstract | Publisher Full Text

13. Atkins DL, Everson-Stewart S, Sears GK, et al:: Epidemiology and outcomes from out-of-hospital cardiac arrest in children: the Resuscitation Outcomes Consortium Epistry-Cardiac Arrest. Circulation. 2009; 119(11): 1484-91. PubMed Abstract | Publisher Full Text | Free Full Text

14. Bardai A, Berdowski J, van der Werf C, et al:: Incidence, causes, and outcomes of out-of-hospital cardiac arrest in children. A comprehensive, prospective, population-based study in the Netherlands. J Am Coll Cardiol. 2011; 57(18): 1822-8.

PubMed Abstract | Publisher Full Text

15. F Gelberg J, Strömsöe A, Hollenberg J, et al.: Improving Survival and Neurologic Function for Younger Age Groups After Out-of-Hospital Cardiac Arrest in Sweden: A 20-Year Comparison. Pediatr Crit Care Med. 2015; 16(8) 750-7.

PubMed Abstract | Publisher Full Text | F1000 Recommendation

16. F Salcido DD, Torres C, Koller AC, et al:: Regional incidence and outcome of out-of-hospital cardiac arrest associated with overdose. Resuscitation. 2016; 99: 13-9.

PubMed Abstract | Publisher Full Text | Free Full Text | F1000 Recommendation

17. Deasy C, Bray JE, Smith $\mathrm{K}$, et al:: Out-of-hospital cardiac arrests in young adults in Melbourne, Australia. Resuscitation. 2011; 82(7): 830-4. PubMed Abstract | Publisher Full Text

18. Iwami T, Nichol G, Hiraide A, et al.: Continuous improvements in "chain of survival" increased survival after out-of-hospital cardiac arrests: a large-scale population-based study. Circulation. 2009; 119(5): 728-34. PubMed Abstract | Publisher Full Text

19. Nitta M, Iwami T, Kitamura T, et al:: Age-specific differences in outcomes after out-of-hospital cardiac arrests. Pediatrics. 2011; 128(4): e812-20. PubMed Abstract | Publisher Full Text

20. Kloner RA, Jennings RB: Consequences of brief ischemia: stunning, preconditioning, and their clinical implications: part 1. Circulation. 2001 104(24): 2981-9.

PubMed Abstract | Publisher Full Text

21. F Hasselqvist-Ax I, Riva G, Herlitz J, et al.: Early cardiopulmonary resuscitation in out-of-hospital cardiac arrest. N Engl J Med. 2015; 372(24):
2307-15

PubMed Abstract | Publisher Full Text | F1000 Recommendation

22. Uray T, Mayr FB, Fitzgibbon J, et al: Socioeconomic factors associated with outcome after cardiac arrest in patients under the age of 65 . Resuscitation. 2015; 93: 14-9.

PubMed Abstract | Publisher Full Text | Free Full Text

23. F Lee SJ, Jeung KW, Lee BK, et al.: Impact of case volume on outcome and performance of targeted temperature management in out-of-hospital cardiac arrest survivors. Am J Emerg Med. 2015; 33(1): 31-6.

PubMed Abstract | Publisher Full Text | F1000 Recommendation

24. F Daya MR, Schmicker RH, Zive DM, et al:: Out-of-hospital cardiac arres survival improving over time: Results from the Resuscitation Outcomes Consortium (ROC). Resuscitation. 2015; 91: 108-15.

PubMed Abstract | Publisher Full Text | Free Full Text | F1000 Recommendation

25. F Kitamura T, Kiyohara K, Sakai T, et al.: Epidemiology and outcome of adult out-of-hospital cardiac arrest of non-cardiac origin in Osaka: a populationbased study. BMJ Open. 2014; 4(12): e006462.

PubMed Abstract | Publisher Full Text | Free Full Text | F1000 Recommendation

26. Patil KD, Halperin HR, Becker LB: Cardiac arrest: resuscitation and reperfusion. Circ Res. 2015; 116(12): 2041-9.

PubMed Abstract | Publisher Full Text

27. F Chan PS, McNally B, Tang F, et al:: Recent trends in survival from out-ofhospital cardiac arrest in the United States. Circulation. 2014; 130(21): 1876-82. PubMed Abstract | Publisher Full Text | Free Full Text | F1000 Recommendation

28. Nichol G, Thomas E, Callaway CW, et al.: Regional variation in out-of-hospital cardiac arrest incidence and outcome. JAMA. 2008; 300(12): 1423-31. PubMed Abstract | Publisher Full Text | Free Full Text

29. F Kitamura T, Iwami T, Kawamura T, et al:: Conventional and chestcompression-only cardiopulmonary resuscitation by bystanders for children who have out-of-hospital cardiac arrests: a prospective, nationwide, population-based cohort study. Lancet. 2010; 375(9723): 1347-54. PubMed Abstract | Publisher Full Text | F1000 Recommendation

30. F Moler FW, Silverstein FS, Holubkov R, et al:: Therapeutic hypothermia after out-of-hospital cardiac arrest in children. N Engl J Med. 2015; 372(20): 1898908.

PubMed Abstract | Publisher Full Text | Free Full Text | F1000 Recommendation

31. Vaagenes $\mathrm{P}$, Safar $\mathrm{P}, \mathrm{Moossy} \mathrm{J}$, et al.: Asphyxiation versus ventricula fibrillation cardiac arrest in dogs. Differences in cerebral resuscitation effects-a preliminary study. Resuscitation. 1997; 35(1): 41-52. PubMed Abstract | Publisher Full Text

32. Weil MH: A comparison of myocardial function after primary cardiac and primary asphyxial cardiac arrest. Am J Respir Crit Care Med. 2002; 166(5): 774 PubMed Abstract | Publisher Full Text

33. Callaway CW, Donnino MW, Fink EL, et al.: Part 8: Post-Cardiac Arrest Care: 2015 American Heart Association Guidelines Update for Cardiopulmonary Resuscitation and Emergency Cardiovascular Care. Circulation. 2015; 132(18 Suppl 2): S465-82. PubMed Abstract | Publisher Full Text | Free Full Text

34. de Caen AR, Berg MD, Chameides L, et al:: Part 12: Pediatric Advanced Life Support: 2015 American Heart Association Guidelines Update for Cardiopulmonary Resuscitation and Emergency Cardiovascular Care. Circulation. 2015; 132(18 Suppl 2): S526-42. PubMed Abstract | Publisher Full Text

35. Atkins DL, Berger S, Duff JP, et al.: Part 11: Pediatric Basic Life Support and Cardiopulmonary Resuscitation Quality: 2015 American Heart Association Guidelines Update for Cardiopulmonary Resuscitation and Emergency Cardiovascular Care. Circulation. 2015; 132(18 Suppl 2): S519-25. PubMed Abstract | Publisher Full Text

36. Kleinman ME, Brennan EE, Goldberger ZD, et al:: Part 5: Adult Basic Life Support and Cardiopulmonary Resuscitation Quality: 2015 American Heart Association Guidelines Update for Cardiopulmonary Resuscitation and Emergency Cardiovascular Care. Circulation. 2015; 132(18 Suppl 2): S414-35. PubMed Abstract | Publisher Full Text

37. Link MS, Berkow LC, Kudenchuk PJ, et al.: Part 7: Adult Advanced Cardiovascular Life Support: 2015 American Heart Association Guidelines Update for Cardiopulmonary Resuscitation and Emergency Cardiovascular Care. Circulation. 2015; 132(18 Suppl 2): S444-64. Care. Circulation. 2015; 132(18 Suppl 2):
PubMed Abstract | Publisher Full Text

38. Hall WL 2nd, Myers JH, Pepe PE, et al.: The perspective of paramedics about on-scene termination of resuscitation efforts for pediatric patients. Resuscitation. 2004: 60(2): 175-87. PubMed Abstract | Publisher Full Text

39. F Sutton RM, Case E, Brown SP, et al:: A quantitative analysis of out-ofhospital pediatric and adolescent resuscitation quality--A report from the ROC epistry-cardiac arrest. Resuscitation. 2015; 93: 150-7. PubMed Abstract | Publisher Full Text | Free Full Text | F1000 Recommendation

40. Idris AH, Guffey D, Aufderheide TP, et al:: Relationship between chest 
compression rates and outcomes from cardiac arrest. Circulation. 2012. 125(24): 3004-12

PubMed Abstract | Publisher Full Text | Free Full Text

41. F Stiell IG, Brown SP, Nichol G, et al.: What is the optimal chest compression depth during out-of-hospital cardiac arrest resuscitation of adult patients? Circulation. 2014; 130(22): 1962-70.

PubMed Abstract | Publisher Full Text | F1000 Recommendation

42. Yakovlev AG, Ota K, Wang G, et al.: Differential expression of apoptotic protease-activating factor- 1 and caspase- 3 genes and susceptibility to apoptosis during brain development and after traumatic brain injury. $J$ Neurosci. 2001; 21(19): 7439-46.

PubMed Abstract

43. Rizzi S, Ori C, Jevtovic-Todorovic V: Timing versus duration: determinants of anesthesia-induced developmental apoptosis in the young mammalian brain. Ann N Y Acad Sci. 2010; 1199: 43-51.

PubMed Abstract | Publisher Full Text | Free Full Text

44. Lee $\mathrm{JH}$, Zhang J, Wei L, et al:: Neurodevelopmental implications of the general anesthesia in neonate and infants. Exp Neurol. 2015; 272: 50-60. PubMed Abstract | Publisher Full Text | Free Full Text

45. Attarian S, Tran LC, Moore A, et al.: The neurodevelopmental impact of neonata morphine administration. Brain Sci. 2014; 4(2): 321-34. PubMed Abstract | Publisher Full Text | Free Full Text

46. F Diaz LK, Gaynor JW, Koh SJ, et al: Increasing cumulative exposure to volatile anesthetic agents is associated with poorer neurodevelopmental outcomes in children with hypoplastic left heart syndrome. J Thorac Cardiovasc Surg. 2016; 152(2): 482-9.

PubMed Abstract | Publisher Full Text | F1000 Recommendation

47. Sayre MR, Berg RA, Cave DM, et al:: Hands-only (compression-only) cardiopulmonary resuscitation: a call to action for bystander response to adults who experience out-of-hospital sudden cardiac arrest: a science advisory for the public from the American Heart Association Emergency Cardiovascular Care Committee. Circulation. 2008; 117(16): 2162-7. PubMed Abstract | Publisher Full Text

48. Hallstrom $\mathrm{A}$, Cobb L, Johnson $\mathrm{E}$, et al:: Cardiopulmonary resuscitation by chest compression alone or with mouth-to-mouth ventilation. N Engl J Med. 2000 342(21): 1546-53.

PubMed Abstract | Publisher Full Text

49. Bohm K, Rosenqvist $\mathrm{M}$, Herlitz J, et al.: Survival is similar after standard treatment and chest compression only in out-of-hospital bystande cardiopulmonary resuscitation. Circulation. 2007; 116(25): 2908-12. PubMed Abstract | Publisher Full Text

50. Hüpfl M, Selig HF, Nagele P: Chest-compression-only versus standard cardiopulmonary resuscitation: a meta-analysis. Lancet. 2010; 376(9752): $1552-7$

PubMed Abstract | Publisher Full Text | Free Full Text

51. Ogawa T, Akahane M, Koike S, et al:: Outcomes of chest compression only CPR versus conventional CPR conducted by lay people in patients with out of hospital cardiopulmonary arrest witnessed by bystanders: nationwide population based observational study. BMJ. 2011; 342: c7106. PubMed Abstract | Publisher Full Text

52. F Dumas F, Rea TD, Fahrenbruch C, et al.: Chest compression alone cardiopulmonary resuscitation is associated with better long-term survival compared with standard cardiopulmonary resuscitation. Circulation. 2013; 127(4): 435-41.

PubMed Abstract | Publisher Full Text | F1000 Recommendation

53. F Iwami T, Kitamura T, Kawamura T, et al.: Chest compression-only cardiopulmonary resuscitation for out-of-hospital cardiac arrest with publicaccess defibrillation: a nationwide cohort study. Circulation. 2012; 126(24): $2844-51$.

PubMed Abstract | Publisher Full Text | F1000 Recommendation

54. F Deasy C, Bray J, Smith K, et al:: Functional outcomes and quality of life of young adults who survive out-of-hospital cardiac arrest. Emerg Med J. 2013; 30(7): 532-7

PubMed Abstract | Publisher Full Text | F1000 Recommendation

55. F Hypothermia after Cardiac Arrest Study Group: Mild therapeutic hypothermia to improve the neurologic outcome after cardiac arrest. N Engl J Med. 2002; 346(8): 549-56.

PubMed Abstract | Publisher Full Text | F1000 Recommendation

56. F Bernard SA, Gray TW, Buist MD, et al:: Treatment of comatose survivors of out-of-hospital cardiac arrest with induced hypothermia. N Engl J Med. 2002; 346(8): 557-63.

PubMed Abstract | Publisher Full Text | F1000 Recommendation

57. F Nielsen N, Wetterslev J, Cronberg $\mathrm{T}$, et al:: Targeted temperature management at $33^{\circ} \mathrm{C}$ versus $36^{\circ} \mathrm{C}$ after cardiac arrest. N Engl J Med. 2013; 369(23): 2197-206.

PubMed Abstract | Publisher Full Text | F1000 Recommendation

58. Che D, Li L, Kopil CM, et al:: Impact of therapeutic hypothermia onset and duration on survival, neurologic function, and neurodegeneration after cardiac arrest. Crit Care Med. 2011; 39(6): 1423-30.

PubMed Abstract | Publisher Full Text | Free Full Tex

59. Creeley CE, Olney JW: The young: neuroapoptosis induced by anesthetics and what to do about it. Anesth Analg. 2010; 110(2): 442-8. PubMed Abstract | Publisher Full Text

60. F Drayna PC, Browne LR, Guse CE, et al: Prehospital Pediatric Care: Opportunities for Training, Treatment, and Research. Prehosp Emerg Care. 2015; 19(3): 441-7.

PubMed Abstract | Publisher Full Text | F1000 Recommendation

61. F Lammers RL, Willoughby-Byrwa M, Fales WD: Errors and error-producing conditions during a simulated, prehospital, pediatric cardiopulmonary arrest Simul Healthc. 2014; 9(3): 174-83.

PubMed Abstract | Publisher Full Text | F1000 Recommendation

62. Park CB, Shin SD, Suh GJ, et al:: Pediatric out-of-hospital cardiac arrest in Korea: A nationwide population-based study. Resuscitation. 2010; 81(5): 512-7. PubMed Abstract | Publisher Full Text

63. López-Herce J, García C, Domínguez P, et al:: Outcome of out-of-hospital cardiorespiratory arrest in children. Pediatr Emerg Care. 2005; 21(12): 807-15. PubMed Abstract

64. F Johnson MA, Grahan BJ, Haukoos JS, et al:: Demographics, bystander CPR, and AED use in out-of-hospital pediatric arrests. Resuscitation. 2014; 85(7): 920-6.

PubMed Abstract | Publisher Full Text | Free Full Text | F1000 Recommendation

65. Schindler MB, Bohn D, Cox PN, et al.: Outcome of out-of-hospital cardiac or respiratory arrest in children. N Engl J Med. 1996; 335(20): 1473-9. PubMed Abstract | Publisher Full Text

66. Rea TD, Cook AJ, Stiell IG, et al:: Predicting survival after out-of-hospital cardiac arrest: role of the Utstein data elements. Ann Emerg Med. 2010; 55(3): 249-57.

PubMed Abstract | Publisher Full Text

67. McNally B, Robb R, Mehta M, et al.: Out-of-hospital cardiac arrest surveillance -- Cardiac Arrest Registry to Enhance Survival (CARES), United States, October 1, 2005--December 31, 2010. MMWR Surveill Summ. 2011; 60(8): 1-19. PubMed Abstract

68. Engdahl J, Axelsson A, Bång A, et al:: The epidemiology of cardiac arrest in children and young adults. Resuscitation. 2003; 58(2): 131-8. PubMed Abstract | Publisher Full Text

69. F Fukuda T, Ohashi-Fukuda N, Matsubara T, et al.: Trends in Outcomes for Out-of-Hospital Cardiac Arrest by Age in Japan: An Observational Study. Medicine (Baltimore). 2015; 94(49): e2049.

PubMed Abstract | Publisher Full Text | Free Full Text | F1000 Recommendation

70. $\mathrm{F}$ Ng YY, Wah W, Liu N, et al:: Associations between gender and cardiac arrest outcomes in Pan-Asian out-of-hospital cardiac arrest patients. Resuscitation. 2016; 102: 116-21.

PubMed Abstract | Publisher Full Text | F1000 Recommendation

71. F Terman SW, Shields TA, Hume B, et al.: The influence of age and chronic medical conditions on neurological outcomes in out of hospital cardiac arrest. Resuscitation. 2015; 89: 169-76.

PubMed Abstract | Publisher Full Text | F1000 Recommendation

72. Herlitz J Svensson L, Engdahl J, et al: Characteristics of cardiac arrest and resuscitation by age group: an analysis from the Swedish Cardiac Arrest Registry. Am J Emerg Med. 2007; 25(9): 1025-31. PubMed Abstract | Publisher Full Text

73. F Wang CY, Wang JY, Teng NC, et al:: The secular trends in the incidence rate and outcomes of out-of-hospital cardiac arrest in Taiwan--a nationwide population-based study. PLOS One. 2015; 10(4): e0122675. PubMed Abstract | Publisher Full Text | Free Full Text | F1000 Recommendation

74. F Wissenberg M, Folke F, Hansen CM, et al:: Survival After Out-of-Hospita Cardiac Arrest in Relation to Age and Early Identification of Patients With Minimal Chance of Long-Term Survival. Circulation. 2015; 131(18): 1536-45. PubMed Abstract | Publisher Full Text | F1000 Recommendation

75. Herlitz J, Eek M, Engdahl J, et al.: Factors at resuscitation and outcome among patients suffering from out of hospital cardiac arrest in relation to age. Resuscitation. 2003; 58(3): 309-17. PubMed Abstract | Publisher Full Text

76. Horsted TI, Rasmussen LS, Meyhoff CS, et al:: Long-term prognosis after out-ofhospital cardiac arrest. Resuscitation. 2007; 72(2): 214-8. PubMed Abstract | Publisher Full Text

77. Deasy C, Bray JE, Smith K, et al:: Out-of-hospital cardiac arrests in the older age groups in Melbourne, Australia. Resuscitation. 2011; 82(4): 398-403. PubMed Abstract | Publisher Full Text

78. F Beesems SG, Blom MT, van der Pas MH, et al.: Comorbidity and favorable neurologic outcome after out-of-hospital cardiac arrest in patients of 70 years and older. Resuscitation. 2015; 94: 33-9.

PubMed Abstract | Publisher Full Text | F1000 Recommendation 


\section{Open Peer Review}

\section{Current Peer Review Status:}

\section{Editorial Note on the Review Process}

Faculty Reviews are review articles written by the prestigious Members of Faculty Opinions. The articles are commissioned and peer reviewed before publication to ensure that the final, published version is comprehensive and accessible. The reviewers who approved the final version are listed with their names and affiliations.

\section{The reviewers who approved this article are:}

\section{Version 1}

\section{Hideo Inaba}

Department of Emergency Medical Science, Kanazawa University Graduate School of Medicine, Kanazawa, Japan

Competing Interests: No competing interests were disclosed.

\section{Tobias Cronberg}

Department of Clinical Sciences, Division of Neurology, Lund University, Lund, Sweden

Competing Interests: No competing interests were disclosed.

The benefits of publishing with F1000Research:

- Your article is published within days, with no editorial bias

- You can publish traditional articles, null/negative results, case reports, data notes and more

- The peer review process is transparent and collaborative

- Your article is indexed in PubMed after passing peer review

- Dedicated customer support at every stage

For pre-submission enquiries, contact research@f1000.com 